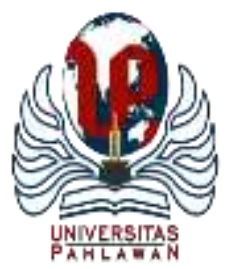

Edukatif : Jurnal Ilmu Pendidikan Volume 4 Nomor 1 Tahun 2022 Halm 211 - 216 EDUKATIF: JURNAL ILMU PENDIDIKAN

Research \& Learning in Education

https:/ledukatif.org/index.php/edukatif/index

\title{
Nyorog Tradition Value in Betawi Societies
}

\section{Bahagia $^{1 凶}$, Rimun Wibowo ${ }^{2}$, Fachruddin Majeri Mangunjaya ${ }^{3}$, Eka Paradila ${ }^{4}$, Nur Afiyah Sulistiyanti $^{5}$, Muhammad Aqil Ibatulloh ${ }^{6}$, Mahesa Rana Kharisma ${ }^{7}$, Muhammad Asyrul Addha $^{8}$, Siti Syafatul Rahmah ${ }^{9}$}

Universitas Ibn Khaldun Bogor, Indonesia ${ }^{1}$, LPM Equator Bogor, Indonesia ${ }^{2}$, Universitas Nasional Jakarta, Indonesia $^{3}$, MI Raudhatul Athfal Rawa Panjang - Bojong Gede, Indonesia ${ }^{4}$, TPA Ittihadul Jadiid Pabuaran Mekar, Cibinong - Bogor, Indonesia ${ }^{5}$, MI Nurul Insan Cibinong - Bogor, Indonesia ${ }^{6}$, TPA Nurussa'adah Bubulak - Bogor, Indonesia ${ }^{7,9}$, Madrasah Diniyah Nurul Ummah - Bogor, Indonesia ${ }^{8}$

E-mail : bahagiagia59@yahoo.co.id

\begin{abstract}
Abstrak
Tujuan dari penelitian ini adalah untuk mengenal nilai-nilai agama Islam yang terdapat dalam tradisi Betawi yaitu tradisi Nyorog. Tradisi nyorog merupakan tradisi yang menghantarkan makanan antar keluarga dan tetangga yang Biasa di laksanakan oleh warga betawi pada saat menjelang hari raya Idul Fitri. Penelitian ini menggunakan jenis penelitian Kualitatif. Pendekatan penelitian yang digunakan adalah penelitian Lapangan Etnografi. Teknik Pengumpulan Sampel dalam penelitian ini menggunakan teknik Purposive Sampling. Hasil penelitian menunjukkan bahwa Nyorog merupakan tradisi pada masyarakat betawi yang masih bertahan meskipun mengalami banyak bentuk perubahan. Temuan lain yaitu terdapat nilai-nilai sosial pada tradisi nyorog meliputi nilai pertemanan antar sesama teman sebab sebagai wadah untuk membangun hubungan sosial. Hubungan keleluargaan juga terbangun secara sosial antara anak muda dan orang yang lebih tua. Selain itu, nyoroh juga mengandung nilai pertolongan sosial sebab nyorog membuat masyarakat menjadi dekat sehingga jika ada musibah pada keluarga maka keluarga dan tetangga ikut membantu. Bahkan terdapat nilai pendekatan sosial pada nyorog dimana ketika ada pengantin baru maka kedua belah pihak mengunjungi setiap keluarga dari pihak perempuan dan laki-laki. Nyorog juga mengandung nilai agama terutama agama Islam sebab perilaku dalam kegiatan Nyorog sesuai dengan ajaran Islam.
\end{abstract}

Keywords: Budaya, Tradisi, Nyorog, Religion, social

\begin{abstract}
The purpose of this study is to identify the Islamic religious values contained in the Betawi tradition, namely the Nyorog tradition. The Nyorog tradition is a tradition that delivers food between family and neighbors which is usually carried out by Betawi residents at the time of Eid al-Fitr. This research uses qualitative research. The research approach used is Ethnographic Field research. The sample collection technique in this study used the purposive sampling technique. The results of the study show that Nyorog is a tradition in Betawi society that still survives despite experiencing many forms of change. Another finding is that there are social values in the Nyorog tradition including the value of friendship between friends because it is a place to build social relationships. Family relationships are also built socially between young people and older people. In addition, Nyorog also contains the value of social assistance because Nyorog makes the community close so that if there is a disaster in the family, the family and neighbors will help. There is even a value of the social approach to Nyorog where when there is a new bride, both parties visit each family from the female and male sides. Nyorog also contains religious values, especially Islam because the behavior in Nyorog activities is in accordance with Islamic teachings.
\end{abstract}

Keywords: Culture, Tradition, Nyorog, Religion, Social

Copyright (c) 2022

Bahagia, Rimun Wibowo, Fachruddin Majeri Mangunjaya, Eka Paradila, Nur Afiyah Sulistiyanti, Muhammad Aqil Ibatulloh, Mahesa Rana Kharisma, Muhammad Asyrul Addha, Siti Syafatul Rahmah

$\triangle$ Corresponding author:

Email : bahagiagia59@yahoo.co.id

DOI : https://doi.org/10.31004/edukatif.v4i1.1006 
212 Nyorog Tradition Value in Betawi Societies - Bahagia, Rimun Wibowo, Fachruddin Majeri Mangunjaya, Eka Paradila, Nur Afiyah Sulistiyanti, Muhammad Aqil Ibatulloh, Mahesa Rana Kharisma, Muhammad Asyrul Addha, Siti Syafatul Rahmah

DOI: https://doi.org/10.31004/edukatif.v4i1.1006

\section{INTRODUCTION}

The diversity of a local heritage that is unique and distinctive from each tribe in Indonesia, make the Indonesian nation a rich and unique nation with a rich local culture inherited by the ancestors and is part of the life of the people who have attached to the joints of life, which were formed through a long process and proven to contain noble values (Magalhaes \& Prodi, 2021). Indonesia is a country with diverse cultures and traditions, almost every ethnic group has a different culture and tradition according to their characteristics each, where the existence of each society can be seen in every sacred event or the daily activities of the community (Aridiantari et al., 2020). Humans gather themselves into a socio-cultural unit, into a society. Public humans give birth, create, grow, and develop culture: none man without culture, and conversely, there is no culture without man, no society without culture, there is no culture without society (Kistanto, 2017). A society can be said to have characteristics that distinguish it from other groups of people because of its different traditions and cultures. Culture is an important thing that characterizes characteristics of a basic living wholeness of society, nation, and state. Besides, fellow Betawi people, defend themselves and save people in need of help (Andrian \& Rifai, 2018).

Tradition is something that is inherited, it does not mean that it must be accepted, appreciated, assimilated, or stored until death because tradition is a picture of human attitudes and behavior that has been in process for a long time and is carried out from generation to generation, starting from the ancestors (Daud et al., 2018). Tradition is a cultural heritage and habit in the previous period which is preserved until nowadays (Bahagia et al., 2021). This tradition is not only in the framework of preserving the traditions of the ancestors, but in it contains noble values. These values are related to three things, namely regarding the relationship between humans and nature, human relations with each other, and human relations with the Creator ( Nugroho \& Hidayat, 2021). One tribe in Indonesia which have numerous cultural diversity is Betawi. Betawi is an ethnic group that is rich in cultural, linguistic, and cultural diversity. Colorful This brings various perceptions, interpretations, and understandings of Betawi, both in terms of the native population, culture, and culture. Some argue that the Betawi population is plural. That is, they come from a mixture of the blood of various ethnic groups and foreign nations (Purbasari, 2010).

The Betawi community in Citayam Depok still maintains a hereditary tradition, namely the Nyorog tradition in everyday life, especially before the holy month of Ramadan and Idul Fitri al-Fitr. Nyorog tradition can be understood substantively as an effort to care for family harmony, as well as a means of physical, spiritual, and social education (Zaelani, 2019). The Nyorog tradition in question is a hereditary habit that is mostly carried out by Muslims in the Betawi community in entering the holy month of Ramadan and ahead of Idul Fitri al-Fitr. This theory shows that Nyorog has some value of social, religion as well as culture. Socially, the Nyorog tradition leads to building social relations and respect for the older person which is young people need to respect. In some tradition like cooperation also have a value that is connected to social aspects. In cooperation tradition, people apply togetherness, willing to help other people as well as conserve charity for assisting people (Mujahidin et al., 2020). Generally, Islamic values teach to adherer to release social life like respect to another person. It is connected to Islamic values where the person is asked to show good traits to older people as well as always link social relation to each person.

Religion as a guideline human life created by the lord of almighty god in lived his life, while culture is the habit or procedures of human life created by human beings themselves from the power of copyright, taste, and karsanya given by god. Religion and culture on each other (Bauto, 2016). Religion and culture are the main elements in an interconnected society. When religion enters a community, there will be a trade-off between the religion and culture e.g. when Islam is descended from Arab which has an old tradition. Tradition is part of a culture, for that it is not a surprise that every country has tradition including Indonesia (Buhori, 
213 Nyorog Tradition Value in Betawi Societies - Bahagia, Rimun Wibowo, Fachruddin Majeri Mangunjaya, Eka Paradila, Nur Afiyah Sulistiyanti, Muhammad Aqil Ibatulloh, Mahesa Rana Kharisma, Muhammad Asyrul Addha, Siti Syafatul Rahmah

DOI: https://doi.org/10.31004/edukatif.v4i1.1006

2017). Even culture and religion don't contradict. The researchers intent to discover about Nyorog tradition value in Betawi societies. Some goals will investigate such as social value comprises the social relation and brotherhood as well as respecting of the older people where the young people must respect to them. The other is to trace about the social value like building social connection among of family when there is a new bride. Lastly, discover religious value in Nyorog tradition.

\section{METHODS}

Research about Nyorog Tradition Value is conducted in Rawa Panjang Village, Betawi Citayam, Depok. The research uses the qualitative method. In this study, the researcher used a qualitative research type. Qualitative research is collecting data in a natural setting to interpret the phenomena that occur where the researcher is the key instrument, sampling of data sources is carried out purposively and snowballing, data collection techniques are triangulation (combined), data analysis is inductive/qualitative, and qualitative research emphasizes meaning rather than generalization (Anggito \& Setiawan, 2018). Meanwhile, ethnography is an anthropological approach that has gained popularity in sociology, cultural studies, communications, consumer research, and marketing, as well as several other fields in the social sciences (Bakry, 2017). The sample collection technique in this study used the purposive sampling technique. Purposive sampling is a sampling technique with certain considerations. The sample in this research is the person who still preserves the tradition of Nyorog in Betawi namely Mr. H. Mansyuri. The person is determined as the respondent because the researchers deem that the person can answer all the questions as the goal of this research.

There are three methods that researchers use to gather the data from the field. To begin with, observation is the first method to observe the location directly. Also to envisage the real situation in the research place. Another way is to perpetrate in-depth-interview with the main respondent. The question rises to respondents including about the tradition value in Nyorog and social aspect of the tradition such as Nyorog tradition can tighten social relations between the young person and older people as well as build social connecting to people in the social environment generally. In addition, the question is connected between social value and the people who just perform new bride. In Nyorog tradition, the young people have a task to visit the family both from the women and the man in a new bride. Lastly, the researcher intends to demand the respondent to reply about whether there is a connection between religion and the Nyorog tradition. Interviews were conducted through a telephone network through WhatsApps. After the data have been collected from indepth-interview, researchers try to combine some sources of research data such as the data from interviews, observation, and documentation. Data can be reliable when the result is based on the blending of some sources in numerous methods.

\section{RESULT AND DISCUSSION}

Based on the results of interviews with Mr. H. Mansyuri who is a native Betawi resident who lives in the Kp. Citayam Depok said that Nyorog was an old tradition that was passed down from generation to generation and is now almost extinct, along with the marginalization of the Betawi community. However, there are still Betawi people who carry it out. For example, such as a kind of social activity in the family that is useful to forgive each other and strengthen the ties of friendship between families. Usually, this Nyorog tradition is held during the fasting month carried out by the younger generation to the older generation by delivering food using a basket containing rice. However, there has been a slight shift between the past and present youth, such as those who generally bring rice and side dishes that are rarely eaten daily, such as meat, which is considered a luxury food, which can be seen that the younger generation only needs to bring basic food items that are brought using minimart plastic which looks simpler. 
Changes that happen in people's lives cover various aspects namely social, cultural, economics, technology, and science knowledge (Gunawan et al., 2015). One factor to transform the culture and abolish the tradition is expanding the state of art. Technology helps and provides convenience in various aspects of human life and increases productivity, but also causes problems or impacts the culture itself. Trigger level changes and shifts in lifestyle from patterns that rely on direct communication with communication using media, the displacement of local wisdom in the context of adat and wider culture (Yoga, 2019). Even Sociocultural change is a symptom of changing social and cultural conditions in a society. Socio-cultural changes are symptoms that always occur in every society (Maryanto \& Azizah, 2019). The next generation will not recognize their culture because has been abolished by globalization periods. Even as it continues, it harms existing local culture and tradition (F M Mangunjaya et al., 2020). Even the cultural influence of modernization is very rational, capitalism, hedonism, consumerism, and the stream of Western culture to Indonesia have an impact on the destruction of the foundations of the system of culture, norms, a tradition so that changes in behavior patterns of society from the value of local knowledge as a social system culture that gives directions foothold in the act (Sutarto, 2016).

In ancient times when religion was not so attached, Betawi people still believed in mystical things, for example, "One place is haunted, must be given offerings or treats". Meanwhile, in Betawi, it is famous that farmers used to plant rice called Dewi Sri and once the rice is ready to be harvested it is an expression of gratitude. As soon as Islam entered and adhered, the tradition was abandoned, offerings or offerings were no longer intended for something mystical, but were shifted to goals based on religious values. The values of etiquette contained in the Nyorog tradition are numerous, in between their busy schedules, with Nyorog we can make friends with each other. Not only the younger generation to the older generation, but the older generation can also come to the younger generation as a form of understanding each other. Another value of etiquette, namely Nyorog, is not only done to relatives but can be done to leaders in the community, as well as neighbors to maintain ties of friendship. As for the values of etiquette to fellow peers, especially the current generation, of course, there are many.

With the existence of media for communication such as cellphones, it is rare or even no time to chat. Cell phones make there is no chat when meeting, there are only friends with friends sitting individually. No chat makes the atmosphere familiar and so on. However, the existence of the Nyorog Tradition can liven up the atmosphere such as small talk, exchange stories, and ask each other how things are, and asking about family news whether they are healthy or not, and very useful for building a social environment between friends. However, the Nyorog tradition can build a family. It's just that it is difficult to impose on the current generation because the current generation is different from the previous generation. There is even a very drastic change in the present, where before fasting we have to visit people who are older than us, for example visiting the uak house. We go with rice. Even when someone is married, they must visit the family of both the family of the woman and the family of the man. The purpose of this activity is to introduce all brothers from the female side to the male side and introduce the male side's family to the female. At the time of visiting there is a tradition where both women and men must bring food and drinks.

When it's finished, the person being visited will give them various gifts. Some were given, namely, they were given rice, glasses, and household utensils. The purpose of this activity is to provide food and household needs for newlyweds. This tradition also produces the value of helping. When Nyorog makes the family closer and they are also close to the neighbors. When experiencing difficulties, the family is also not reluctant to help because they have done the same thing. Likewise with neighbors, when we are close to neighbors, neighbors will also want to help when experiencing difficulties. So without being asked the neighbor will also come. For example, in the past, building a house was done together with neighbors when not familiar causes problems with family values. As for the religious values that exist in the Nyorog Tradition, namely at least the growth of 
215 Nyorog Tradition Value in Betawi Societies - Bahagia, Rimun Wibowo, Fachruddin Majeri Mangunjaya, Eka Paradila, Nur Afiyah Sulistiyanti, Muhammad Aqil Ibatulloh, Mahesa Rana Kharisma, Muhammad Asyrul Addha, Siti Syafatul Rahmah

DOI: https://doi.org/10.31004/edukatif.v4i1.1006

gratitude that we pray to Allah SWT who is not arbitrarily, gratitude is expressed by gathering with family, namely, tahlilan, reading the letter al fatihah, and praying for the grave expert, where the family becomes the Our goal is to be blessed. It is supported that the community preserve the mutual assisting among of them like helping the sick people and try to omit the burden as well as giving some money to help them (Bahagia et al., 2021). In addition, social capital such as helping each other, working hand in hand, and doing good to each other has become a tradition for the community (Bahagia et al., 2021). Even cooperation has been released through some activity including mutual assisting, mutual working, mutual giving collectively instead of individual-level (Bahagia et al., 2021).

However, this activity is not open only to the nuclear family. Neighbors or community members were not included Mr. Mansyuri also said that Nyorog was not always carried out before the Ramadan Fasting Service and before Idul Fitri, in fact at any time it could be said that the Nyorog tradition was carried out when the younger generation brought fruits such as oranges and starfruit, it's just that the time is different. most highlighted to do Nyorog before the fasting month and before Idul Fitri. Nyorog can be done at any time, for example, a sick family is brought cake or fruit, another example is a celebration event and then thanksgiving is held. Head of Rt. Rw and the head of the hamlet were brought food first. It's just that the moment is different because it's not before Ramadan and Idul Fitri. Usually, the Nyorog Tradition is carried out a week before Idul Fitri, not the $\mathrm{H}$ day so that the food brought does not become wasteful. In the past, Nyorog was carried out the day before Idul Fitri, and food was brought in using a basket, and nowadays Nyorog is brought in using a basket. The Nyorog tradition is exciting because it has many religious values, etiquette, and intimacy as well as togetherness that arises. The Nyorog tradition is also useful for building communication with friends.

\section{CONCLUSION}

Usually, this Nyorog tradition is held during the fasting month carried out by the younger generation to the older generation by delivering food using a basket containing rice. However, there has been a slight shift between the past and present youth, such as those who generally bring rice and side dishes that are rarely eaten daily, such as meat, which is considered a luxury food, which can be seen that the younger generation only needs to bring basic food items that are brought using minimart plastic such as Indomaret which looks simpler. As soon as Islam entered and adhered, the tradition was abandoned, offerings or offerings were no longer intended for something mystical, but were shifted to goals based on religious values. As for the religious values that exist in the Nyorog Tradition, namely the growth of gratitude that we pray to Allah SWT who is not arbitrary, gratitude is expressed by gathering with family, namely, tahlilan, reading al-Fatihah letters, and praying for grave experts, at the family's destination. us to be blessed. Neighbors or community members were not included Mr. Mansyuri also said that Nyorog was not always carried out before the Ramadhan Fasting Service and before Idul Fitri. most highlighted to do Nyorog before the fasting month and before Idul Fitri.

\section{REFERENCES}

Andrian, S. N., \& Rifai, A. (2018). Ideologi Masyarakat Betawi Dalam Novel Kronik Betawi Karya Ratih Kumala. Pbsi, 6(1), 75-89.

Anggito, A., Setiawan, J., (2018) Metodologi Penelitian Kualitatif. Sukabumi: CV Jejak.

Aridiantari, P., Lasmawan, I. W., \& Suastika, I. N. (2020). Eksistensi Tradisi Dan Budaya Masyarakat Bali. Ganesha Civic Education, 2(2), 67-80.

Artikel, I., \& Info, A. (n.d.). Nilai-Nilai Tasawuf dalam Tradisi Keagamaan ( Studi Kasus terhadap Komunitas Aboge di Desa Mudal, Kecamatan Mojotengah ). 8(1), 68-77. 
216 Nyorog Tradition Value in Betawi Societies - Bahagia, Rimun Wibowo, Fachruddin Majeri Mangunjaya, Eka Paradila, Nur Afiyah Sulistiyanti, Muhammad Aqil Ibatulloh, Mahesa Rana Kharisma, Muhammad Asyrul Addha, Siti Syafatul Rahmah

DOI: https://doi.org/10.31004/edukatif.v4i1.1006

Bahagia, B., Rahmadanti, R., \& Indriya, I. (2021). Societies Resilience for Confronting Covid-19 Based on Gotong Royong Tradition (Mutual Cooperation). Tunas Geografi, 9(2), 119.

https://doi.org/10.24114/tgeo.v9i2.20221

Bahagia., Majeri, F.M., Wibowo, R., Rangkuti, Z., \& Noor, Z. M. (2021). Edukatif: Jurnal Ilmu Pendidikan Tradition of Cleaning For Reacting Social, Religion and Environment Education. 3(5), 1971-1981.

Bahagia., Majeri, F.M., Wibowo, R., Rangkuti, Z., \& Noor, Z. M. (2021). Edukatif: Jurnal Ilmu Pendidikan Social and Religion Value of Muludan and Mutual Assisting in Community. 3(6), 3654-3662.

Bakry, U. S. (2017). Pemanfaatan Metode Etnografi dan Netnografi Dalam Penelitian Hubungan Internasional. Jurnal Global \& Strategis, 11(1), 15. https://doi.org/10.20473/jgs.11.1.2017.15-26

Bauto, L. M. (2016). Perspektif Agama dan Kebudayaan dalam Kehidupan Masyarakat Indonesia (Suatu Tinjauan Sosiologi Agama). Jurnal Pendidikan Ilmu Sosial, 23(2), 11. https://doi.org/10.17509/jpis.v23i2.1616

Buhori, B. (2017). Islam dan Tradisi Lokal di Nusantara (Telaah Kritis Terhadap Tradisi Pelet Betteng Pada Masyarakat Madura dalam Perspektif Hukum Islam). Al-Maslahah Jurnal Ilmu Syariah, 13(2), 229. https://doi.org/10.24260/almaslahah.v13i2.926

Daud, W., Arifin, S., \& D, D. (2018). Analisis Tuturan Tradisi Upacara Ladung Bio' Suku Dayak Kenyah Lepo' Tau di desa Nawang Baru Kecamatan Kayan Hulu Kabupaten Malinau: Kajian Folklor. Jurnal Ilmu Budaya, 2(2), 167-174.

Gunawan, H., Suryadi, K., \& Malihah, E. (2015). Analisis Perubahan Sosial Budaya Masyarakat Desa Cihideung Sebagai Desa Wisata. Sosietas, 5(2). https://doi.org/10.17509/sosietas.v5i2.1524

Habibah, N. W., Mangunjaya, F. M., \& Wibowo, R. (2021). Edukatif: Jurnal Ilmu Pendidikan Religion Value and Social Capital for Resilience to Combat Covid-19 in Society Environment. 3(5), 2441-2449.

Kistanto, N. H. (2017). Tentang Konsep Kebudayaan. Sabda: Jurnal Kajian Kebudayaan, 10(2), 1-11. https://doi.org/10.14710/sabda.v10i2.13248

Magalhaes, A. D. J., \& Prodi. (2021). Nilai tais dalam tradisi kematian masyarakat suku kemak di kabupaten belu. 2(08), 50-55. file:///C:/Users/Asus/Downloads/433-Article Text-1062-1-10-20210319.pdf

Mangunjaya, F M, Bahagia, B., Wibowo, R., \& ... (2020). Nujuh bulanan Tradition Value For Societies Resilience in Costumary Community Urug Bogor West Java. Sosial ..., 17(2). http://ejournal.uinsuska.ac.id/index.php/SosialBudaya/article/view/10960

Maryanto, \& Azizah, L. N. (2019). Perubahan Sosial Budaya Masyarakat Desa Ngebalrejo Akibat Kemajuan Ilmu Pengetahuan dan Teknologi. Indonesian Journal of Social Science Education (IJSSE), 1(2), 181190. https://journal.iainbengkulu.ac.id/index.php/ijsse/article/view/2247

Mujahidin, E., Bahagia, B., Wibowo, R., \& Mangunjaya, F. M. (2020). Rereongan Serumpi for Rural Development in Situ Udik Village Bogor West Java. Jhss (Journal of Humanities and Social Studies), 4(2), 96-101. https://doi.org/10.33751/jhss.v4i2.2454

Purbasari, M. (2010). Indahnya Betawi. Humaniora, l(1), 1. https://doi.org/10.21512/humaniora.v1i1.2142

Sutarto, D. (2016). Kearifan Budaya Lokal Dalam Pengutan Tradisi Malemang Di Tengah Masyarakat Modernisasi Di Sungai Keruh Musi Banyuasin Sumatera Selatan. Jurnal Dimensi, 5(3), 2-6. https://doi.org/10.33373/dms.v5i3.54

Yoga, S. (2019). Perubahan Sosial Budaya Masyarakat Indonesia dan Perkembangan Teknologi Komunikasi. Jurnal Al-Bayan, 24(1), 29-46. https://doi.org/10.22373/albayan.v24i1.3175

Zaelani, A. Q. (2019). Nyorog Tradition of Betawi Community in The Perspective of Abdul Qodir Zaelani Syari ' ah Faculty of Raden Intan UIN Lampung Tradisi Nyorog Masyarakat Betawi dalam Perspektif Hukum. Al-Ulum, 19(1), 215-238. 